\title{
Banking in Shadow of Globalization
}

\author{
Asst. Prof. Dr. Fatma Nur Yorgancilar (Selçuk University, Turkey) \\ Prof. Dr. Haldun Soydal (Selçuk University, Turkey) \\ Prof. Dr. Bedriye Tunçsiper (İzmir Demokrasi University, Turkey)
}

\begin{abstract}
The sector having the most important role among developedness indicators is financial sector. The most important and vulnerable part of this sector is banking system. Financial liberalization and relaxation in political approach, based on strict norms, following it, and increasing competition at sectorial level required the presence of supervision mechanisms. The rigid rules of supervision system under consideration led profit margin to fall gradually. Hence, alternative searches became a current issue in terms of the other actors of banks and banking system. These alternative ways, developed and termed off-balance sheet activities despite the fall at profitability level, are shown as one of the main reasons for 2008 Global Crisis by some economists and draw attention to the concept of shadow banking. In USA, together with the synthesis of liberalization and financial engineering, "Shadow Banking" system formed as the main reason for 2008 Crisis and played role in its development. In this study, the effects of shadow banking on world banking are dealt with the theoretical meaning, and a set of economic policy are suggested in the light of the data obtained.
\end{abstract}

\section{Introduction}

In respect of $80 \mathrm{~s}$, when globalization gains acceleration, country economies played the role of a macro structure, in which the borders disappeared in the sense of international trade and investments. Especially emerging market economies, in terms of all of world countries after globalization, financial liberalization tendencies increased and financial sector became much more important. As a matter of fact, world countries, as a part of integration under consideration, are directly affected from the developments occurring in the other countries. The closest example of this state is 2008 Global Financial Crisis.

The sector having the most important role among the developedness indicators is financial sector, and the most vulnerable and important part of this sector is banking sector. Financial liberalization and relaxation in political approach, based on strict norms, following it and increasing competition at sectorial level required the presence of supervision mechanisms. The rigid rules of supervision system under consideration led profit margin to fall gradually. Hence, alternative searches became a current issue in terms of the other actors of banks and banking system. These alternative ways, developed and termed off-balance sheet activities despite the fall at profitability level, are shown as one of the main reasons for 2008 Global Crisis by some economists and draws attention to the concept of shadow banking. In USA, together with the synthesis of liberalization and financial engineering, "Shadow Banking" system formed as the main reason for 2008 Crisis and played role in its development (Doruk, 2014: 1).

\section{Shadow Banking System: Conceptual Framework}

Shadow Banking, defined by TCMB (Central Bank of the Turkish Republic) as "nonbank credit mediation activities having risks like banking sector", expresses a system, which does not subject to as strict arrangements as banking sector, engages in activity of maturity transformations like banks, and exposes to liquidity risk and risks resulted from high leverage $\left(\mathrm{TCMB}_{2} 2014\right.$ : 99). Although shadow banking system ranging in realization of chainconnected transactions to each other emerges as a result of that traditional banking system becomes useless in terms of banking system, it is based on a running related to traditional banking system. On the other hand, this new system has a structure that forms after the financial engineering, deregulations, and incentive -based public policies. In other words, through off-balance sheet transactions, it is also to define shadow banking as forming an alternative market to the traditional system for the aims such as increasing competitive power and profitability. According to Gorton (2009), it is possible to collect the reasons for shadow banking to emerge under three items (Haltom, 2010: 22-23):

1. Traditional banking system becoming less profitable

2. Emerging trend of institutional investments

3. The guarantee accompanied by banking system regulated in terms of secured liabilities

On the other hand, the formation of shadow banking system depends on two factors in terms of supply and demand (Gorton an Metrick, 2010: 266):

1. When the factors are scrutinized in terms of supply, it is remarkable that financial innovation series and legal changes eliminate the competitive advantage of the banks.

2. When considered from the aspect of demand, what is under consideration is that the instruments of shadow banking are used as security deposit due to the fact that security deposit is demanded for financial 
transactions. This case, leading securitization to develop and repo to become an effective reason for it to be used as an instrument of monetary market, was concluded that repo transactions are also begun to be effectively used as an instrument of monetary market.

Before proceeding to the historical process, instruments, and causes and effects of shadow banking, first used by Culley (2007) (Moe, 2012: 37), it will be useful to mention about its relationship with traditional banking system. Shadow banking system exhibiting a completely different structure from traditional banking system in terms of either its instruments or supervision methods comes to forefront in terms of traditional system to minimize the costs reducing profit margin. In the viewpoint of traditional banking, among the duties assigned to the actors of banking sector, creating liquidity, financial mediation, contributing to providing economic stability by supporting monetary policies, determining credit demand, and approach of determining and credit demand and preventing the problem with asymmetric information as fast as possible take place. And all of these processes actualize in bank balance sheet.

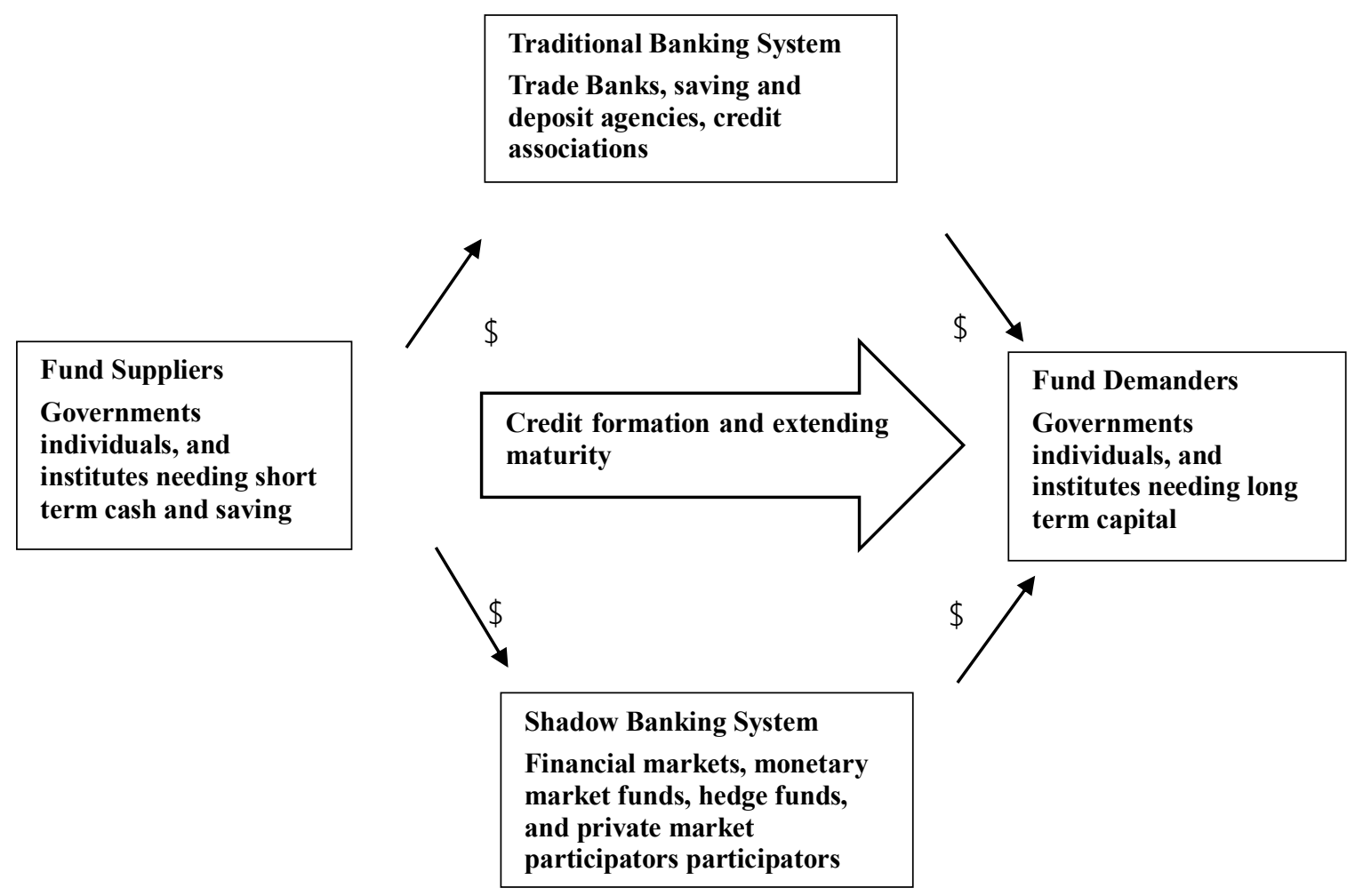

Figure 1. The Relationship of Traditional Banking System and Shadow Banking System Resource: FCIC, 2010:10

As seen in Figure 1 summarizing the rules and shadow banking, along the processes carried out, short term savings are tried to be transformed into long term capital resources. While trade banks and their branches are exposed to new sorts of financial risks, they participate in shadow banking market so that it can be a source of extra income for themselves (Doruk and Şahintürk, ty: 10).

Shadow banking system that occurs after financial liberalization tendencies and showing itself in the form of an amount over \$ 20 trillion after global crisis (Watkins, 2011: 857) differs from traditional system in terms of funding resources. Table 1 presents the distinctions between traditional and shadow banking systems (Doruk, 2014: 33 ). 


\begin{tabular}{|c|c|}
\hline Traditional Banking & Shadow Banking \\
\hline (1) Reserves & (1)Risk Margin \\
\hline $\begin{array}{l}\text {-Minimum levels are determined by legal } \\
\text { authority. } \\
\text {-It can be borrowed from central banks for } \\
\text { capital deficit. }\end{array}$ & $\begin{array}{l}\text {-Minimum levels are determined by the parts. } \\
\text {-There is no borrowing from central bank. }\end{array}$ \\
\hline (2) Deposit Insurance & (2)Security Deposit \\
\hline -It is under government guarantee. & $\begin{array}{l}\text { - Cash, treasury bond, securities, credit, and } \\
\text { securitized bonds. }\end{array}$ \\
\hline (3) Deposit Interest Rate & (3)Repo Rates \\
\hline $\begin{array}{l}\text { - Interest rates can be increased to mobilize } \\
\text { deposits, when reserves are low }\end{array}$ & $\begin{array}{l}\text { - While funds are at the low level, it can be } \\
\text { increased to mobilize the parts. }\end{array}$ \\
\hline \multirow{2}{*}{ (4) Credits take place in balance sheet. } & (4)Securitized Credits \\
\hline & $\begin{array}{l}\text { - Some securitized bonds are held in the balance } \\
\text { sheet and used as }\end{array}$ \\
\hline
\end{tabular}

Table 1. Main Distinctions between Traditional and Shadow Banking Systems Resource: Gorton and Metrick, 2009: 38 .

Table 1 shows the main funding resources of shadow banking system and traditional banking system. According to this, the main resource of shadow banking system is repo market as well as risk margin depending on repo market and balance sheet activities. The other funding resource of the system is securitized values. On the other hand, the most remarkable feature, in which traditional banking differentiates from shadow banking system is deposit insurance. Shadow banking system do not have any insurance such as state guarantee and asset /deposit insurance. Figure 1 shows running of shadow banking system.

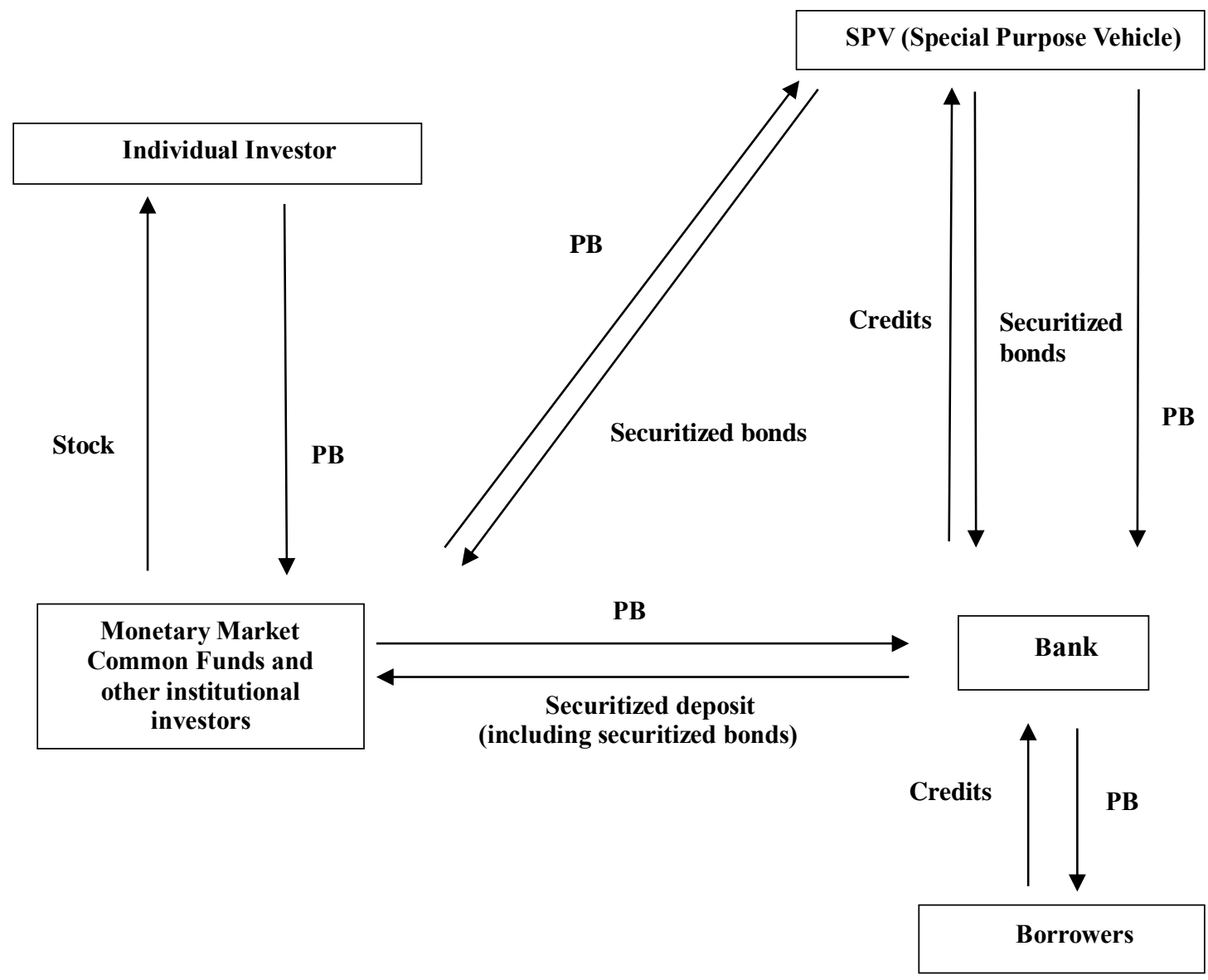

Figure 2. Running of Shadow Banking Resource: Gorton and Metrick, 2010: 264; Cited by Doruk, 2014: 29.

On the other hand, although shadow banking is an alternative of traditional banking system in terms of method, it brings together some risks with it in both national and global dimension. It is possible to basically describe the risks of interests in two ways. 
1. Funds that are processed in the system are not under government guarantee.

2. In possible depression periods, the actors of shadow banking cannot refer to central bank about financing the existing liquidity deficits.

In addition, it is possible to collect the main elements of the relationship between traditional and shadow system under three items.

1. Capital Adequacy (Legal) Arbitrage: In order to utilize price differences forming the different markets, arbitrage expressing the process to buy and sell valued securities and provide return by this way (Güçlü, 2006: 6) is the main elements in preferring shadow banking helping to obtain profit without being any effect of off- balance sheet transactions on capital adequacy and leverage. In this process leading systemic risk not to be able to be completely calculate, in order to compensate the effect of long term housing credits on capital adequacy, shadow banking was preferred by the traditional banks by means of legal arbitrage (Önal, ty. 31).

2. Obtaining long term profit and distributing risk to the system: [Due to the fact] that funding possibilities of banking system and risk coming together with funding mechanism stay on a single bank, that profitability of equity capital is low, shadow banking has become attractive among the banks in terms of that it facilitates risk to go out balance sheet (Stein, 2010: 41-51) and that it makes possible it to be shared by the system

3. Tax Advantage: According to Turner (2010), banks utilizing activities of shadow banking obtain a tax advantage in terms of that activities of shadow banking are off -balance sheet processes that are not recognized and, thus, that they do not subject to any tax (Cited by 2014: 51).

Besides its relationship with traditional system, another feature of shadow banking system is that it consists of the combination of trade banking system and investment banks. In other words, the system of interest uses together the mechanism of assets taken over from trade banking and funding taken over from investment banking. Figure 1 represents the feature and scope of interest of shadow banking.

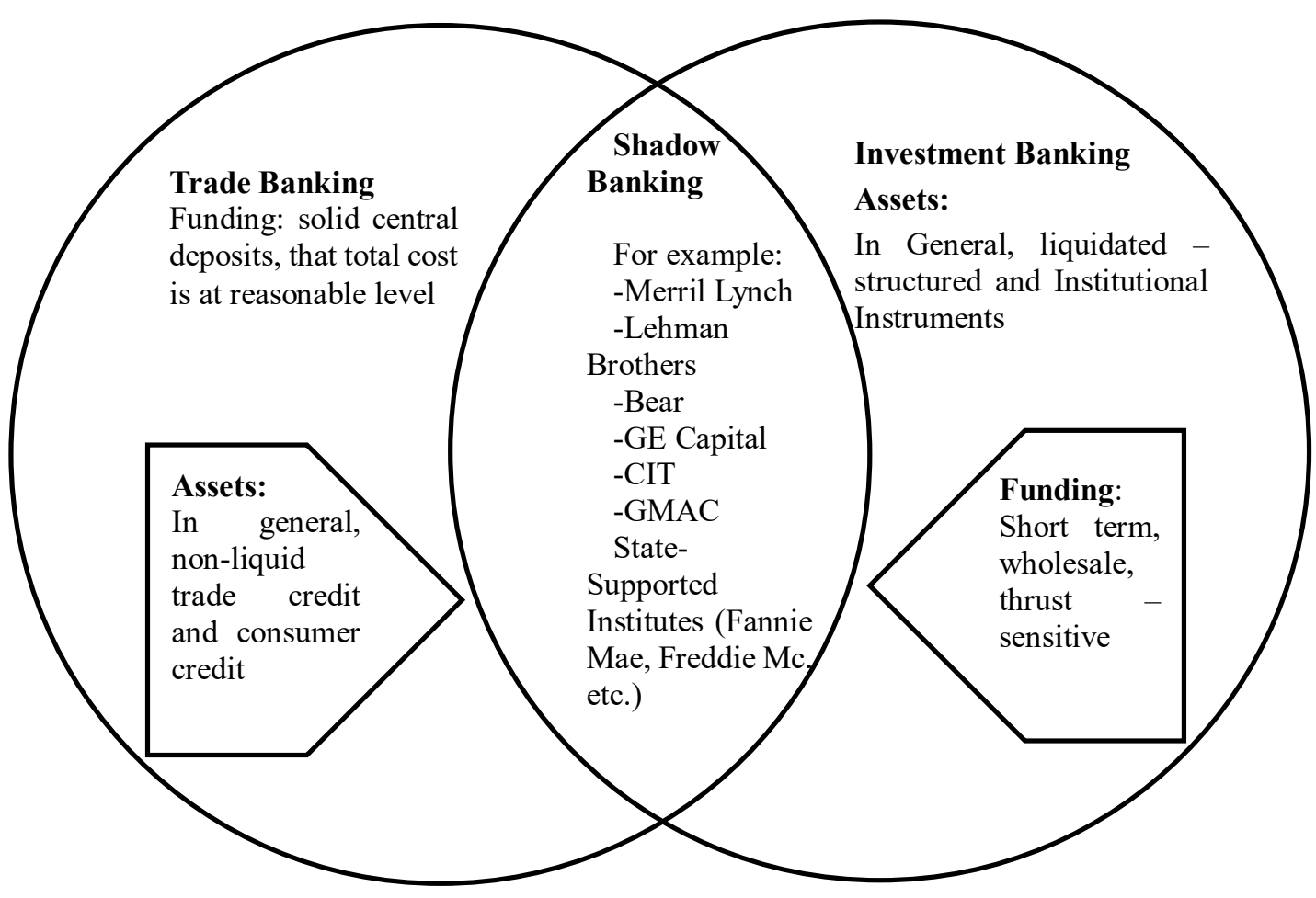

Figure 3. The Scope of Shadow Banking System Resource: Cited by Doruk, 2014: 28.

Shadow banking has a structure that does not subject to capital and liquidity arrangements like traditional banking. Therefore, system, besides financial depths it creates, engenders some risks. On the other hand, in the periods, when regulations toward banking sector become strict, a possibility of regulation arbitrage emerges, and activities of shadow banking can rapidly grow. Monitoring and supervising activities of shadow banking under consideration and developing policy suggestions toward these activities are left to Financial Stability Board (FSB). FSB, which determine its works in two parts as monitoring and supervising activities, presents the volume of shadow banking activities, its relationship with traditional sector, and risk it creates through monitoring reports published every year TCMB, 2013: 147) and determines five basic working areas (BDDK, 2011: 15);

1. Regulation of activities of shadow banking agencies of banks, defined in the form of direct regulation.

2. Reform associated with regulation of monetary market funds 
3. Especially withholding and transparency, regulation associated with securitization

4. Possible precautions regulating discounts and limits toward repo transactions

5. Regulations regarding the other agencies of shadow banking

For the presence of shadow banking, it is necessary for two conditions more to actualize. The first condition is the features in tax structure of the countries. For example, in Anglo-Saxon countries, governments do not have the rights to impose tax without parliament approval. Therefore, shadow banking system can also remain nontax in terms of its activities. On the other hand, the second condition is that the legal system of country is suitable for presenting a limitless freedom to the parts. The reason for this is that shadow banking system is mostly based on the specific contracts. In contrast to the structure of traditional bank, regulated by laws, this specific structure of shadow banking will not have any risk in case that the contracts are made between equal parts. On the other hand, in case that the parts are not equal, shadow banking system can engender results in favor of the part that is strong.

These two conditions are fulfilled in United States (US) and United Kingdom. Therefore, shadow banking system has a large share in, especially US, all EU member countries. The size of activity volume in US is followed by the developed countries such as Eurozone, United Kingdom, and Japan. However, in Continental Europe, European Union, and Japan, it is allowed for shadow banking system to be active in a framework drawn by the laws. Therefore, shadow banking in these countries is more slowly progressing compared to US and United Kingdom. After global crisis, while the growth rate of the sector, which it becomes slower in the developed economies, actualizes over $20 \%$ in China, Argentina, India, and South Africa, it is seen that the growth range in the developing countries keeps its acceleration.

There is a set of elements affecting this systematic development of shadow banking. It is possible to put in order these elements as financial innovations, deregulation, subprime housing credits, special purpose vehicle, repo market, and credit delinquency swap (CDS).

1. Financial Innovations: That financial innovations increase and become widespread led the systems alternative to banking system to emerge and nonbank activities to increase. When reached from 1950 to 1980 , the fluctuation range in interest rates increased. Fluctuations of interest cause the uncertainty about the return of investments to increase. This increase in the risk of interest rate led new financial products such as adjustable interest mortgage and derivatives to develop (Mishkin, 2011: 251).

2. Deregulation: Applications in quality of deregulation are the other elements enabling shadow banking system to develop. In this context, as the most important deregulation, abrogation of Glass Steagal Law eliminating the distinction of investment bank and trade bank can be shown. Thus, with this development, it became possible that banking system continued without being regulated. Also, investment banks having less capital power compared to trade banks became more advantageous in terms of competition (Önal, ty: 10).

3. Subprime housing credits: Subprime housing mortgage credits are the credits allocated to the consumers remaining under "prime -rate" borrowing scale in higher interest rates (subprime rates ) compared to prime-rate that is the cheapest borrowing rate. In other words, in an environment, in which such credits are allocated, consumers are not accepted as homogenous in terms of debt servicing risk, on the contrary, they are divided into marketing segments according to the states of riskiness with a heterogeneous viewpoint. These credits were issued by special purpose institutes in order to be securitized to off-balance sheet. Securities based on credits are based on cash flows based on these credits. Any shortage forming in these cash flows caused to malfunctions in the system. With an arrangement carried out beginning from 2004, that credits are also allocated to the individuals who do not have their regular incomes or assets expressed as subprime led balloon forming in housing market to inflate (Oktar snf Eroğlu, 2015: 308).

4. Special Purpose Vehicles: Special Purpose Vehicles (SPV) is private organizations, whose capital is generally weak, which does not have independent management and staff and, most importantly, and which are designed not to go bankrupt and found only CDO transactions. Mc Culley, drawing attention the existence of nonbank financial agencies, instruments, and structures, states that shadow banks financed themselves unsecured financing bonds. The agencies, instruments, and structures that are under consideration here, as a whole, are qualified as special purpose vehicles (Schwarcz, 2012: 620, Oktar and Eroğlu, 2015: 310).

5. Repo market: Financial agencies, with short term funds they provide through transactions with securitized transactions, can make leveraged procedures. Since the security deposits used in these procedures are the subject of re-securitization, interagency bound relationships increase. Beside this, variations in asset values, modifying the amount of fund to be able to be provided, make deeper the cyclicality in economy. Therefore, securitized transactions form some risks in terms of financial stability (TCMB, 2014: 109). It revealed that banks allocating long term housing credits, in order to successfully continue their trade activities, needed reserve Income model of shadow banking system is repo market (Reiboldt, 2009).

6. Credit Delinquency Swap (Swaps) The volume of Credit Delinquency Swaps (CDS) toward being protected from risk and utilizing arbitrage possibility reached high levels in the period of global crisis and especially European crisis attracted attention with high basis points. In CDS procedure, the debt side are under obligation of paying the debt it receives both capital and interest to the side it receives debt at the end of the period. Lending 
side observes the state of debtor in the market and, in case that it faces the risk to go into default, in order to guarantee the return, it will obtain at the end of the period, signs a CDS contracts with another part that is voluntary to share risk. According to this, in case of bankruptcy of the debtor, obtains its loss from protection seller. Thus, credit risk is not collected on a single part and both risk is reduced and return is obtained due to the fact that risks are differently perceived by the parts (Choudhry, 2006'den Cited by. Hanc1, 2014: 2).

Credit rating: While Credit ratings give information about solvency of the country, institute, company, project, obligation, etc., CDS premiums give information about the solvency of credits used (debtor) by the country, company, or institute. As the risk of debtor rises, CDS premiums rise, and credit ratings falls. On the other hand, since CDS procedures are continuously conducted in the day of transaction (since CDS premiums are continuously priced), the perceptions of market participants about the credibility of debtor quickly reflects to CDS premiums. In this sense, the rise and fall of CDS premiums functions as a continuous indicator about the credibility of debtors. Credit ratings are modified, when the view that an adjustment has to be done in the position of the part rated formed in the mind of credit rating specialist. Hence, the variations in credibility of the part rated reflect to credit ratings with delay. On the other hand, it is possible to say that CDS premiums are more sensitive indicators compared to credit ratings (Saylgan, 2014: 2).

\section{Sorts of Shadow Banking System}

Pozsar et al. (2012) classify shadow banking system under four categories as three main subgroups and one parallel banking system (Pozsar et al., 2012: 13).

1. Government - supported shadow banking subsystem: Government - supported shadow banking subsystem defined in the form of that government - supported banks take place in the market and realize the transactions of shadow banking, is shadow banking subsystem emerging with foundation(1932) of Federal House Lending Banking (FHLB) (Pozsar et al., 2012: 13). The most important stone of the system is that investor thinks that it has a guarantee mechanism in the direction of that state guarantee is provided for government- supported institutes. The system under consideration consists of a total of four stages as storing credits, credit risk transfer by means of credit insurance, providing "form - distribute securitization functions" for banks by Fannie Mae and Freddie Mac, and providing maturity transformation. For Government -supported shadow banking subsystem attracting attention with its structure shaped in US, Infonavit and Fovissste in Mexico can be shown as an example.

2. Internal shadow banking subsystem: Beginning from the early 1980s, that large banks proceed from low equity profitability to high equity profitability played quite important role in application of shadow banking system. Thanks to this, it was proceeded from equity funding to institutional funding; it was moved from the process, in which difference of exchange rate is effective, to the process, in which market is effective; and market risk increased, while credit risk intensity decreased (Pozsar et al, 2010: 22). Although the process of interest forms and develops in the legal framework of financial holding companies, it legitimated with repealing Glass-Steagall Law. Credit mediation process, which can be realized horizontally and vertically, is carried out by application of off-balance sheet securitization and techniques of asset management. In internal shadow banking subsystem, other than credit mediation of these companies, European banks has also shadow banking activities. The participation of these banks in shadow banking credit mediation is limited (Pozsar et al, 2010: 23-30; Cited by. Yiğenoğlu, 2016 : 734).

3. External shadow banking subsystem: External Shadow Banking, defined as shadow banking subsystem, which are realized by nonbank financial institutes and which hold the aim of obtaining gain, are generally shadow banking activities, generally diversified and managed by the independent institute. It is in the leadership of special investment vehicles (STV) Landesbanks has and security agent in Germany. On the other hand, the other large European banks and Japan banks are also important investors of shadow banking (Pozsar et al., 2012). The structure of interest, in respect of its content, is expressed as credit mediation process, in which the target of legal capital arbitrage is less and which aims to obtain gain from vertical integration (Pozsar et al, 2012).

4. Parallel Banking: Parallel banking taking place in the scope of external shadow banking, in order to obtain specialization and advantage over shadow banking, is expressed as shadow banking subsystem realizing activities such as forming debt, service, trade, and funding in scale economy (Pozsar et al., 2012). Although parallel banking system is based on specialization, the main target of the system, focusing on specialization of nonbank institutes and off-balance sheet transactions, is to enable them to obtain competitive advantage and superiority against banks (Pozsar et al, 2010: 45).

\section{The Benefits and Risks of Shadow Banking System}

It is necessary to actualize a set of major factors toward that shadow banking can run. Therefore, first of all, a fund inflow, which is not in the form of deposit and which actualizes in similar ways, must be to the system. On the other hand, it is necessary for shadow banking to be transferring type of maturity or liquidity to the other sorts of maturity or liquidity. In addition, it means being able to continuously credit risks. Fourth condition is to use 
direct or indirect financial leverage (FSB, 2011). For being able to mention about shadow banking activities, it is necessary for a financial institute to be fulfilling at least one of these transactions counted. In addition to these conditions, for shadow banking to be able to exist, it is suggested that only credit mediations and maturity transfers are not enough and that it is necessary for system to be able to create the secure and short termed cash assets/ (Cited from Tarullo, 2012: 4 by Tarhan, 2013: 7). All of this running has the positive and negative effects in terms of both country economy and investors and global financial system. Table 2 summarizes the advantages and disadvantages of shadow banking.

\begin{tabular}{|c|c|}
\hline \multicolumn{1}{|c|}{ Advantages } & \multicolumn{1}{c|}{ Disadvantages } \\
\hline $\begin{array}{c}\text { By means of shadow banking both extra fund is provided } \\
\text { for the system and bills in portfolio can be retransformed } \\
\text { into liquidity via securitization by the various instruments. }\end{array}$ & $\begin{array}{c}\text { As in traditional banking system, there can be maturity } \\
\text { unconformity and liquidity risk. Therefore, some escapes } \\
\text { can be in stressed periods and, since shadow banking } \\
\text { institutes do not subject to precautionary regulations like } \\
\text { banks, the effect of risks can be larger for these institutes. }\end{array}$ \\
\hline $\begin{array}{c}\text { Through nonbank channels, credit mediation activities } \\
\text { can be performed and, thanks to this, positive contribution } \\
\text { can be made to financial deepening. Hence, it positively } \\
\text { affects the finance of real economy. }\end{array}$ & $\begin{array}{c}\text { In the cases, in which asset prices are high and discount } \\
\text { rates, applied to securitized funding, are low, non-deposit } \\
\text { funding resources lead these agencies to increase leverage } \\
\text { rates and can increase cyclicality in financial markets. }\end{array}$ \\
\hline $\begin{array}{l}\text { In contrast to the others, shadow banking agencies, } \\
\text { diversifying financial credit, increase access to credit and } \\
\text { makes more effective financial system. }\end{array}$ & $\begin{array}{c}\text { Complex shadow banking activities bring together with it } \\
\text { the problems resulted from information asymmetry and in } \\
\text { the periods of crisis and before crisis, for example, investors } \\
\text { investing on mortgage -backed securities do not correctly } \\
\text { perceive the risks due to inadequate information. }\end{array}$ \\
\hline $\begin{array}{l}\text { With alternative financing mechanisms, presented by } \\
\text { shadow banking, financial system can become stronger and } \\
\text { innovative. }\end{array}$ & $\begin{array}{c}\text { With shadow banking system, connectedness between the } \\
\text { other financial agencies, can lead to systemic risk. This case } \\
\text { increases contagion risk. }\end{array}$ \\
\hline $\begin{array}{l}\text { Distribution of risks to out of traditional banking system } \\
\text { can be useful for financial system and mechanisms it can } \\
\text { diversify investors' appetite. }\end{array}$ & $\begin{array}{c}\text { As a result of the events such as escapes to high quality } \\
\text { assets and closeout, the depth of financial stress can increase. } \\
\text { This case, also reducing asset prices much more, deepened } \\
\text { financial stress and can also cause traditional banks to be } \\
\text { affected from this stress. }\end{array}$ \\
\hline
\end{tabular}

Table 2. Advantage and Disadvantages of Shadow Banking System

As seen in the table, shadow banking system, besides some advantages it has in terms of running and profitability level, brings together with it a set of risks. Due to the risks it holds, five working area of FSB are expressed toward the risk subjects put in order as follows (TCMB, 2013: 147);

1. The relationship of shadow banking and banking and reduction of contagion risk,

2. Reduction of the risks the escape of monetary market funds will create,

3. Becoming securitization transactions transparent and standardized,

4. Reducing risks resulted from transactions of lending repo and security

5. Identifying and reducing from the other shadow banking agencies and activities

As a matter of fact, these risks ignored in the rise periods of shadow banking became more remarkable and deep, and they were accepted as one of important reasons of global crisis.

\section{Conclusion and Discussion}

Although shadow banking system, accepted as one of the reasons for global crisis, is a mechanism that is full of uncertainties, it attracts attention in terms of advantages it has, compared to traditional banking system. Shadow banking system mentioned in many studies, even it is criticized due to asymmetries it causes, becomes widespread every passing day and continue to develop. On the other hand, it is clear that the risks it is accompanied by should not be ignored.

As known, in shadow banking, whose main actors are hedge funds, derivatives, common funds of monetary market, and repo market, securitization transactions passed to the privilege of shadow banking, which cannot be adequately supervised and which forms a bridge between trade banks and investment banks. Trade banks, thanks to this, can supply more funds and can make more loan available. On the other hand, again by means of these instruments, it is possible for risk to spread across market instead of a single institute and, with this state of it, banks can provide higher activity volume and profitability. In spite of this, the system of interest, as in the period of global crisis, remained out of supervision and, engendering the possibilities to make use of legal gaps, made financial crisis deeper. Hence, by means of legal regulations, in which advantages featured, it is clear that forming a shadow banking, in which disadvantages can be minimized as much as possible, is a point that countries have to give importance in global economic order. 


\section{References}

- Bankacıllk Düzenleme ve Denetleme Kurumu (BDDK) (2011). Risk Bülteni. Risk Yönetimi İdaresi, Ekim. Web: https://www.bddk.org.tr

- Choudhry, M. (2006). The Credit Default Swap Basis. Bloomberg Press, New York.

- Doruk, Ö. T. \& Şahintürk, Y. (t.y.). 2008 Küresel Krizinde Gölge Bankacllk Sektörünün Rolü ve Reel Sektör ve Finansal Sektör Illişkisi: Minsky'nin Finansal Kırllganlık Hipotezi Çerçevesinde Bir İnceleme. Web: http://www.academia.edu/

- Doruk, Ö. T. (2014). Gölge Bankacıllk ve Türkiye. Türkiye Bankalar Birliği, G.M. Matbaacılık ve Ticaret A.Ş., İstanbul.

- Financial Stability Board (FSB). (2011). Shadow Banking: Scoping the Issues. Washington D. C. Web: http://www.fsb.org/wp-content/uploads/__110412a.pdf

- Financial Stability Board (FSB). (2013). Global Shadow Banking Monitoring Report 2013. Web: http://www.fsb.org/wp-content/uploads/r_131114.pdf?page_moved=1

- Gorton, G. \& Metrick, A. (2009). Securitized Banking and The Run on Repo. NBER Working Paper Series. WP $15223,1-33$.

- Gorton, G. (2009). The Subprime Panic. European Financial Management,15:1,10-46.

- Güçlü, H. (2006). Arbitaj Fiyatlama Modeli. Web: http://www.hakanguclu.com/.

- Haltom, R. C. (2010). Out from Shadows: The Run on Shadow Banking System and a Framework for Reform. Region Focus, Third Quarter (2010: Q3), 22-25.

- Hancı, G. (2014). Kredi Temerrüt Takasları ve BIST - 100 Arasındaki İlişkinin İncelenmesi. Üretim Ekonomisi Kongresi, 21-22 Mart.

- Moe, T. G. (2012). Shadow Banking and the Limits of Central Bank Liquidity Support: How to Achieve a Better Balance between Global and Official Liquidity. Levy Economics Institute of Bard College Working Paper no.712.

- Oktar, S. ve Eroğlu, N. (2016). 2007 Küresel Finansal Kriz ve Gölge Bankacllk. Marmara Üniversitesi, İ.İ.B.F. Dergisi, Cilt XXXVII, Sayı II, Doi No: 10.14780/iibd.44978.

- Önal, B. Y. (t.y.). Gölge Bankacıllk. Ders Notları. Web:

http://www.finansekol.com/dersnot/3/BANKA\%20VE\%20SERMAYE\%20P\%C4\%B0Y.G\%C3\%9CN.KON U.\%2088\%20\%20G\%C3\%96LGE\%20BANKACILIK.pdf

- Pozsar, Z., Adrian, T., Ashcraft, A. \& Boesky, H. (2010). Shadow Banking. Federal Reserve Bank of New York Staff Reports, No: 458.

- Sayılgan, G. (2014). Kredi Temerrüt Swapı Puanları ile Kredi Derecelendirme Notlarının Karşılaştırılması. Web: http://www.guvensayilgan.com/wp-content/uploads/2014/09/Kredi-Temerr\%C3\%BCtSwaplar\%C4\%B1-ve-Kredi-Dereceleri.pdf

- Schwarcz, S. L. (2012). Regulating Shadow Banking. Review of Banking\&Financial Law, Volume 31.

- Stein, J. C. (2010). Securitization, shadow banking \& financial fragility. Deedalus, Journal of the American Academy of Arts and Sciences, Volume 139, Issue 4.

- Tarhan, A. (2013). Gölge Bankacılık ve 2008 Krizi: Ekonomik Çöküş. Web: http://www.academia.edu/7936440/G\%C3\%B6lge_Bankac\%C4\%B11\%C4\%B1k_ve_2008_Krizi

- Tarullo, D. K. (2012). Shadow Banking After the Financial Crisis. Federal Reserve Bank of San Francisco Conference on Challenges in Global Finance. Web: https://www.federalreserve.gov/newsevents/speech/tarullo20120612a.htm

- TCMB (2013). Finansal İstikrar Raporu. Web: http://www.tcmb.gov.tr

- TCMB (2014). Finansal Ístikrar Raporu, Kasım. Web: http://www.tcmb.gov.tr

- Watkins, P. (2011). Shadow Banking: Accounting for Canada's Productivity Gap. International Journal of Productivityand Performance Management, 60:8, 857.

- Yiğenoğlu, K. (2016). Gölge Bankacılık Sistemi: Küresel Piyasalar İçin Yeni Bir Tehdit mi?. Akademik Bakuş Dergisi, Sayı: 54, Mart - Nisan. 